\title{
Evaluation of Healthy Nutrition Index-2015, Dental Health and Oral Flora Relationship in School-Age Children
}

\author{
Dicle Kargin $^{1}$, B.Irem Omurtag Korkmaz ${ }^{1}$, Nil Ceren Mungan² ${ }^{\mathbb{D}}$, Serap Akyuz ${ }^{2}$ (D) \\ ${ }^{1}$ Marmara University, Institue of Health Sciences, Department of Nutrition and Dietetics, Istanbul, Turkey. \\ ${ }^{2}$ Marmara University, Faculty of Dentistry, Department of Pediatric Dentistry, Istanbul, Turkey. \\ Correspondence Author: Dicle Kargin \\ E-mail: dicle.kargin @marmara.edu.tr \\ Received: 17.05.2021 Accepted: 09.08.2021
}

\begin{abstract}
Objective: The aim of the study is to evaluate the role of diet quality and oral flora on the dental health in the childhood period.

Methods: A cross-sectional study was carried out with the participation of 98 children aged 9-14 and their parents who applied to the Pedodontics Clinic Dental Faculty of Marmara University. The decayed, missing, filled tooth and surfaces and DMFT, DMFS indexes were determined through visual dental examination. Anthropometric measurements and saliva samples, as well as $24 \mathrm{~h}$ food consumption records, were taken from each child. Saliva samples were analysed microbiologically. To evaluate dietary quality from intakes Healthy Eating Index-2015 (HEl-2015) scores were calculated.

Results: The mean age of children was $10.8 \pm 1.5$ and study sample compromised $44.9 \%$ males and $55.1 \%$ females. $75 \%$ of the children had normal height and $58.2 \%$ of them had normal BMI according to World Health Organisation (WHO) references. The mean number of decayed tooth and surface was $3.07 \pm 2.35 ; 4.34 \pm 3.78$ respectively and the mean number of DMFT and DMFS indexes were $5.88 \pm 2.31 ; 8.05 \pm 4.58$ respectively. The mean number of decayed, missing, filled teeth and DMFT, DMFS scores were found to be higher in children with poor diets (according to HEI-2015) but the difference was not statistically significant ( $p>0.05$ ). The presence of lactobacilli in saliva samples of $5.5 \%$ of the children was observed and children have lactobacilli in their saliva samples had more decayed teeth $(p<0.05)$.

Conclusion: The study findings illustrate the relationship between decay development and lactobacilli. Further studies with high sample sizes are needed to examine the diet quality and oral health.

Keywords: Healthy eating index, Dental caries, Diet quality, Childhood, Oral flora.
\end{abstract}

\section{INTRODUCTION}

In parallel with the definition of the general health status of the World Health Organization (WHO), it is emphasized that oral and dental health is the starting and basic point of body health (1). Despite improvements in oral disease prevention and treatment over the past decade incidence of dental caries, the most common oral disease, remains high in pediatric age. A systematic review conducted in 2015 reveals that 2.4 billion people are affected by caries in permanent teeth, while 621 million children are affected by caries in deciduous teeth, demonstrating the 10th most prevalent condition worldwide (2). Childhood dental caries have unfavorable effects on the life quality of children due to disturbance, pain, altered sleeping habits, poor nutrition, and even a decrease in school attendance and performance $(3,4)$.

Oral health and nutrition are interdependent and have multidirectional relationship (5). Depend on previous research evidence, diet is still an important factor associated with dental caries and considered to be a main cause of dental erosion $(6,7)$. A good quality diet, which is one of the most important factors contributing to the health and quality of life of children and adolescents, is the only and valid way to prevent dental caries (6) with proper oral hygiene practices (5).

Until today various tools have been developed to assess diet quality. The Healthy Eating Index-2015 (HEI-2015), the most current version, is a dietary assessment tool prepared for this purpose and designed to measure specifically the degree to which a set of foods aligns with the Dietary Guidelines for Americans (8). In HEI-2015 diet quality is evaluated from two perspectives: the first part is adequacy (dietary components to increase) and the second part is moderation (dietary components to decrease) (9). Analyses demonstrated that $\mathrm{HEI}-2015$ is a valid and reliable source in other aspects also 
can be used to evaluate the diet quality of children older than two years as in different populations $(8,10)$. Thirteen components of the HEI-2015 show consistency with Dietary Guidelines for Americans, recommendations of World Health Organisation as well as dietary guidelines of Turkey $(8,11$, 12).

The role of the host microbiota in the health of the individual has been an ongoing and distinct concept for many years (13). The oral cavity is densely colonized with bacteria, dietlike environmental changes may alter the composition of the oral microbiome, and as a result of dysbiosis the risk for oral diseases especially dental caries can increase (14). Streptococcus mutans and Lactobacillus species, which produce acid from bacteria that colonize the oral cavity, are associated with dental caries and cause various oral health problems (15).

The present study aims to evaluate the relationship of dietary intake, as measured by healthy eating index 2015, and oral health indicators in school-age children and the presence of lactobacilli in the oral flora.

\section{METHODS}

A cross-sectional study was carried out with the participation of children between the ages of 9-14 who applied to Pediatric Dentistry Department of Marmara University Faculty of Dentistry, Turkey. Exclusion criteria were; the children who had any mental or physical conditions, chronic diseases, and those who were taking any antibiotics 2 weeks before the examination. The families of the children were informed about the content and duration of the study in written and verbal by the researcher. A voluntary consent form was signed by the families who accepted to participate in the study. The approval of the research was obtained from Marmara University Faculty of Dentistry Clinical Research Ethics Committee. (The date, 20.12.2016; the number, 2016-66). The questionnaire created to be used in the study consists of two parts: demographic and general information about parents and children, and information on oral and dental health. In addition, food consumption records were taken with the 24-hour recall method to determine the nutritional status of the children. The answers given to the questionnaire and the 24-h recalls were recorded in line with the answers given by the children and their families.

\subsection{Sample size estimation}

The sample of the study was chosen by random sampling method, and the sample size was aimed to include 88 children with a minimum of $5 \%$ sampling error, 0,5 confidence interval, $95 \%$ confidence level, and $10 \%$ margin of error. The study was finished with the participation of 44 boys and 54 girls, a total of 98 children. Saliva samples were taken from 91 children due to reasons such as not being able to provide enough saliva or/and not want to give saliva.

\subsection{Dental examination}

Oral and dental examinations of the children were performed by a qualified dentist using a sterile dental mirror at the clinic. Decayed, missing, and filled teeth in permanent teeth were processed into pre-prepared forms according to WHO criteria (16). Soft tissue evaluation and dental anomalies were recorded. The total number of decayed, missing, and filled teeth (Decayed, Missing, And Filled Teeth: DMFT) and tooth surfaces (Decayed, Missing, And Filled Surfaces: DMFS) were calculated, and the mean number of DMFT or DMFS were calculated. The level of caries experience in permanent dentition was determined by the WHO severity criteria for the age groups of children (12 years), levels of DMFT; low < 2.6, moderate $2.7-4.4$, high 4.5-6.5, very high >6.5 (17).

\subsection{Anthropometric measurements}

Anthropometric measurements of the participants were taken by a nutrition and dietetics specialist. The height measurements of the participants were taken with a portable height meter with the feet side by side and the head in the Frankfurt plane and body weights were taken by removing the thick clothes and shoes with a portable body scale. BMI of the children were evaluated according to age and gender by using WHO Anthro Plus Program according to the WHO 2007 reference for ages 5-19 (18).

\subsection{Evaluation of food consumption}

In order to identify the nutritional status of children, 24hour food records were taken based on the child's family and child's responses. And evaluated by using the Healthy Eating Index 2015. HEI-2015 consist of thirteen components, while increasing levels of intake receive increasingly higher scores for components adequacy (Total Fruits, Whole Fruits, Total Vegetables, Greens and Beans, vegetables or beans and peas, Whole Grains, Dairy, Total Protein Foods, Seafood and Plant Proteins, Fatty Acids), increasing levels of intake receive decreasingly lower scores for components moderation (Refined Grains, Sodium, Added Sugars, Saturated Fats) (8). The scores of the 13 components were summed up to obtain the final score of the HEI-2015 for each child, which ranged from 0 to 100. For final scores; HEI-2015 <50 "poor diet", $50<\mathrm{HEl}-2015<80$ "diet needs improvement", HEI-2015>80 signify "good diet" (19).

\subsection{Collection of saliva samples and microbiological analysis}

Unstimulated mixed saliva was collected from participants in the study two hours after breakfast. The children were asked to spit on the saliva accumulated in the mouth into a widemouthed sterile disposable box. Each of the samples was recorded with the same number as the questionnaire and delivered to the laboratory as soon as possible and taken for microbiological analysis.

For the lactobacilli analysis from saliva, the study of Ravindran et al. was followed (20). Loopful saliva was taken and streaked 
on a plate with Rogosa SL agar. Samples were incubated at $37^{\circ} \mathrm{C}$ for 48 hours under an anaerobic environment. After the incubation period, transparent white colonies growing in petri dishes were obtained as suspicious Lactobacillus spp. And gram stained. A pure single colony was obtained by passaging the suspected samples and gram (+) lactobacilli identified after the biochemical testing with a negative oxidase reaction to Catalase/Oxy Test (Liofilchem).

\subsection{Statistical Analysis}

Data were transferred to the electronic environment, tabulated, and analyzed using the Statistical Package for Social Sciences (SPSS) version 22.0 (SPSS Inc., Chicago, IL, USA). In independent groups, the difference and significance between averages were examined according to whether they met the parametric conditions. Since the difference between the means in two independent groups did not conform to the normal distribution, the Mann-Whitney $U$ test was used to analyze the data, while the Kruskal-Wallis test was used for more than two independent groups. The difference between groups in categorical variables was controlled by the chi-square test. Pearson's correlation test was used to examine the correlations between variables. Significance was assessed at 0.05 levels.

\section{RESULTS}

The age of the children in the study ranged from 9 to 14 years with a mean of $10.8 \pm 1.5$. The study sample compromised 44.9\% males and $55.1 \%$ females. Mean weight, height and body mass index of children are $38.3 \pm 10.9,141.9 \pm 11.44$ and $18.6 \pm 3.08$ respectively. When the $\mathrm{BMI}$ and height measurements of the children were classified according to gender and WHO references, it was seen that $75 \%$ of the children had normal height and $58.2 \%$ of them had normal BMI ( $p>0.05)$ (Table 1).

Table 1. Distribution of children's height and BMI measurements by WHO growth references

\begin{tabular}{|c|c|c|c|c|c|c|c|}
\hline & & & $(n: 44)$ & Gir & $n: 54)$ & & ::98) \\
\hline \multirow{4}{*}{ 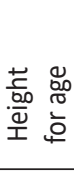 } & & $\mathrm{n}$ & $\%$ & $\mathrm{n}$ & $\%$ & $n$ & $\%$ \\
\hline & Short & 6 & 13.6 & 7 & 12.9 & 13 & 13.3 \\
\hline & Normal & 32 & 72.8 & 42 & 77.8 & 74 & 75.5 \\
\hline & Tall & 6 & 13.6 & 5 & 9.3 & 11 & 11.2 \\
\hline \multirow{4}{*}{ 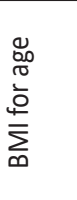 } & Underweight & 4 & 9.1 & 3 & 5.6 & 7 & 7.1 \\
\hline & Healthy weight & 28 & 63.6 & 29 & 53.7 & 57 & 58.2 \\
\hline & Overweight & 9 & 20.5 & 16 & 29.6 & 25 & 25.5 \\
\hline & Obese & 3 & 6.8 & 6 & 11.1 & 9 & 9.2 \\
\hline
\end{tabular}

BMI: Body Mass Index

The number of decayed, missing, filled teeth and tooth surfaces and the mean, minimum and maximum values of DMFT and DMFS indexes of the children were given in Table 2. The mean of decayed, missing, and filled teeth number was $3.07 \pm 2.35 ; 0.10 \pm 0.48 ; 2.75 \pm 2.17$, respectively. The mean number of DMFT and DMFS indexes were 5.88 \pm 2.31 ; $8.05 \pm 4.58$, respectively (Table 2 ).

Table 2. The values of decayed, missing, filled teeth and tooth surface and DMFT, DMFS indexes

\begin{tabular}{llll} 
& Mean (SD) & Min & Max \\
\hline Decayed teeth & $3.07 \pm 2.35$ & 0 & 10 \\
Decayed tooth surface & $4.34 \pm 3.78$ & 0 & 17 \\
Missing teeth & $0.10 \pm 0.48$ & 0 & 4 \\
Missing tooth surface & $0.51 \pm 2.43$ & 0 & 20 \\
Filled teeth & $2.75 \pm 2.17$ & 0 & 12 \\
Filled tooth surface & $3.11 \pm 2.38$ & 0 & 12 \\
DMFT & $5.88 \pm 2.31$ & 1 & 12 \\
DMFS & $8.05 \pm 4.58$ & 1 & 29
\end{tabular}

DMFT: decayed, missing and filled teeth; DMFS: decayed, missing and filled tooth surfaces

While $63.2 \%$ of the children brush their teeth regularly, $24.5 \%$ did not brush their teeth regularly. $60.7 \%$ of those who brush their teeth brush once a day, $39.3 \%$ of them brush twice a day. There was no significant difference between the presence and number of decayed, missing, filled teeth and tooth brushing presence or brushing frequency $(p>0.05)$ (Table 3).

Table 3. Comparison of the oral health indicators and HEI-2015 group

\begin{tabular}{llll}
\hline \multicolumn{4}{c}{ HEI-2015 Group } \\
& Poor diet & Diet needs improvement & P value \\
\hline Decayed teeth & $3.10 \pm 2.40$ & $2.87 \pm 2.09$ & 0.83 \\
Missing teeth & $0.12 \pm 0.53$ & $0.00 \pm 0.00$ & 0.26 \\
Filling teeth & $2.89 \pm 2.28$ & $2.50 \pm 1.54$ & 0.86 \\
DMFT & $6.02 \pm 2.26$ & $5.18 \pm 2.53$ & 0.21 \\
DMFS & $8.32 \pm 4.64$ & $6.62 \pm 4.12$ & 0.07 \\
\hline
\end{tabular}

DMFT: decayed, missing and filled teeth; DMFS: decayed, missing and filled surfaces, HEl-2015: Healthy Eating Index 2015 (Mann Whitney U test)

The mean HEl-2015 score of the group was $40.39 \pm 9.66$ and, it was observed that $83.7 \%$ had a "poor diet" and the diet of $16.3 \%$ was "needs improvement". When the oral health indicators are evaluated according to HEI-2015 the mean number of decayed, missing, filled teeth and DMFT, DMFS scores were found to be higher in children with poor diets but the difference was not statistically significant $(p>0.05)$ (Table 4).

In Table 5, the relationship between the mean score of thirteen $\mathrm{HEI}$ components and DMFT index groups was evaluated, and no significant difference was observed between the groups (Table 5).

The presence of lactobacilli in saliva samples of $5.5 \%$ of the children was observed (Not shown in Table). The relationship between the presence of lactobacilli in saliva samples and oral health indicators given in Table 6. It was observed that children have lactobacilli in their saliva samples had more decayed teeth $(p<0.05)$. 
Table 4. Comparison of the HEI-2015 components among the DMFT group

\begin{tabular}{|c|c|c|c|c|c|}
\hline \multirow[t]{2}{*}{$\begin{array}{c}\text { HEI-2015 } \\
\text { components }\end{array}$} & \multicolumn{5}{|c|}{$\begin{array}{c}\text { DMFT group } \\
\text { Mean (SD) }\end{array}$} \\
\hline & Low & Moderate & High & Very high & $\begin{array}{l}\mathrm{P} \\
\text { value }\end{array}$ \\
\hline Total Fruits & $2.68 \pm 2,49$ & $2.30 \pm 2,05$ & $1,81 \pm 2,13$ & $1,82 \pm 2,12$ & 0.69 \\
\hline Whole Fruits & $3.00 \pm 2.73$ & $1,80 \pm 2,40$ & $1,79 \pm 2,53$ & $1.84 \pm 2.31$ & 0.76 \\
\hline $\begin{array}{l}\text { Total } \\
\text { Vegetables }\end{array}$ & $1.64 \pm 2.1$ & $1,49 \pm 1.57$ & $1.30 \pm 1.66$ & $0.99 \pm 1.06$ & 0.77 \\
\hline $\begin{array}{l}\text { Greens and } \\
\text { Beans }\end{array}$ & $1.34 \pm 1.53$ & $1.80 \pm 2.10$ & $1.55 \pm 2.13$ & $1.71 \pm 2.04$ & 0.92 \\
\hline Whole Grains & $2.00 \pm 4.47$ & $2.08 \pm 4.14$ & $2.36 \pm 4.01$ & $2.04 \pm 3.82$ & 0.88 \\
\hline Dairy & $6.36 \pm 3.61$ & $5.58 \pm 3.56$ & $5.49 \pm 3.92$ & $6.00 \pm .3 .57$ & 0.94 \\
\hline $\begin{array}{l}\text { Total Protein } \\
\text { Foods }\end{array}$ & $4.10 \pm 0.84$ & $3.18 \pm 1.83$ & $3.09 \pm 1.90$ & $3.06 \pm 1.87$ & 0.74 \\
\hline $\begin{array}{l}\text { Seafood } \\
\text { and Plant } \\
\text { Proteins }\end{array}$ & $4.06 \pm 0.59$ & $2.92 \pm 1.37$ & $3.64 \pm 1.40$ & $3.14 \pm 2.02$ & 0.09 \\
\hline Fatty Acids & $1.54 \pm 2.37$ & $1.63 \pm 2.51$ & $1.51 \pm 2.58$ & $1.66 \pm 2.90$ & 0.98 \\
\hline $\begin{array}{l}\text { Refined } \\
\text { Grains }\end{array}$ & $0.24 \pm 0.53$ & $0.42 \pm 1.46$ & $0.83 \pm 2.23$ & $0.67 \pm 1.75$ & 0.77 \\
\hline Sodium & $4.00 \pm 3.82$ & $2.50 \pm 3.31$ & $3.70 \pm 3.44$ & $4.18 \pm 3.51$ & 0.21 \\
\hline Added Sugars & $10.00 \pm 0.00$ & $9.72 \pm 0.93$ & $9.82 \pm 0.58$ & $9.68 \pm 1.27$ & 0.65 \\
\hline $\begin{array}{l}\text { Saturated } \\
\text { Fats }\end{array}$ & $4.76 \pm 2.24$ & $2.88 \pm 2.60$ & $3.87 \pm 3.72$ & $3.76 \pm 3.46$ & 0.59 \\
\hline Total score & $45.72 \pm 10.03$ & $38.37 \pm 9.42$ & $40.81 \pm 9.63$ & $40.61 \pm 9.86$ & 0.51 \\
\hline
\end{tabular}

DMFT: decayed, missing and filled teeth, HEI-2015: Healthy Eating Index 2015 (Kruskal Wallis test)

Table 5. The relationship between the presence of lactobacilli in saliva samples and oral health indicators

\begin{tabular}{llll} 
& Yes $(\mathrm{n}: 5)$ & No $(\mathrm{n}: 86)$ & P value \\
\hline Decayed teeth & $5,8 \pm 3.34$ & $2.81 \pm 2.17$ & $\mathbf{0 , 0 4 2}$ \\
Missing teeth & $0.00 \pm 0.00$ & $0.11 \pm 0.51$ & 0,544 \\
Filling teeth & $1.60 \pm 1.51$ & $2.81 \pm 2.24$ & 0,204 \\
DMFT & $7.40 \pm 2.60$ & $5.70 \pm 2.32$ & 0,146 \\
DMFS & $11.80 \pm 10.05$ & $7.56 \pm 3.88$ & 0,415
\end{tabular}

DMFT: decayed, missing and filled teeth; DMFS: decayed, missing and filled surfaces (Mann Whitney $U$ test)

\section{DISCUSSION}

Good and favorable oral health is precisely important in childhood and oral health diseases such as dental caries have a considerable impact on self-esteem, school performance, eating ability, and a child's quality of life from early childhood to later period $(5,21,22)$. According to WHO it's important to reduce the prevalence of caries, which is known to be an infectious and transmissible multifactorial disease accepted to be "triggered" by improper dietary habits (23). Among the many etiological factors, diet has been determined as a specific type of risk factor that draws attention to the development of caries in children (24). This study examined the relationship between diet quality according to Healthy Eating Index 2015 and oral health and oral flora in schoolage children.
Within the scope of the research children between the ages of 9-14, which is the age group of the children during their primary education, were included. Anthropometric measurements used in the evaluation of growth and development in children and interpretation of height for age and $\mathrm{BMI}$ values for age are important in terms of disease risk assessment. In the TBSA 2010 study, when the height for age status of the children between the ages of 9-14 was examined, it was seen that $57.5 \%-61.1 \%$ had normal height, while this rate was found to be $75 \%$ in our study (25). When the BMI for age (for the 9-14 age group) is examined in the TBSA data for normal weight, it is seen that the range of $55.1 \%-56.8 \%$ is similar to our study (58.2\%). The present study population showed similar anthropometric measurements compared with the population of Turkey for the same age groups.

Dental caries, which is still a crucial health problem in developed countries, affects $60-90 \%$ of school-age children (26). While it is less common in African countries around the world, it is more common in Asian and Latin American countries (1). According to the research profile of oral and dental health of 12 and 15 years age of children in Turkey, caries prevalence was respectively $61.1 \%$ and $61.2 \%$; the prevalence of filling was $6.5 \%$ and $12.4 \%$, respectively (27). In previous studies conducted with similar age groups, the prevalence of caries was found between $71.2 \%$ and $82.6 \%$, parallel to the prevalence in our study $(85.6 \%)(28,29)$. While the mean DMFT index of $5.88 \pm 2.31$ in this study was similar to the averages obtained from various studies $(27,30-32)$, it was observed that it was higher than the averages obtained from other studies $(28,29,33,34)$.

Regular tooth brushing habits and frequency of tooth brushing are known as two important factors in preventing caries formation. In this study, $24.5 \%$ of the children did not brush their teeth regularly and there was no significant difference between the number of decayed, missing, filled teeth and brushing frequency $(p>0.05)$ similar to the findings in the previous study (24). The main reason for this situation may be the lack of information about the appropriate brushing method and/or the biased over reporting of the frequency of brushing by the parents (24).

Among different foods, dietary sugars, juices, and starchy foods have been suggested to have high cariogenic potential. Apart from those foods, there are foods such as milk, dairy products, and whole grain foods that show anticariogenic effects (35). Undoubtedly cariogenic and anticariogenic foods have an impact on dental caries, however the effect of nutritional status receives insufficient attention. Adoption of healthy eating habits may have positive effects on oral health. HEI-2015, used as one of the most up-to-date tools for dietary assessment comprises all of the major food groups found in MyPyramid.

The impact and quality of dietary intake on oral health status have been investigated infrequently. In this study, Healthy Eating Index-2015, a valid and reliable screening tool, was used to evaluate diet quality. To our knowledge, HEI-2015 utilization has not been reported to identify the relationship 
between nutritional status and dental caries, DMFT index in older children. In our study, the mean number of decayed, missing, filled teeth and DMFT, DMFS scores were found to be higher in children with poor diets $(p>0.05)$. Studies evaluating the relationship between Healthy Nutrition Index and childhood dental caries are limited in the literature; however, they have focused especially on early childhood caries in the younger age group (24, 35-37). Unlike our study, previous studies revealed that children with higher HEI scores were less likely to have risk of early childhood caries $(25,36,37)$. A study which comprise National Health and Nutrition Examination Survey population over 20 years old evaluating the HEI2015 and coronal caries found a relationship between $\mathrm{HEI}$ quintiles and DMFT index, although the relationship was not consistent among all racial or ethnic groups (38). Apart from the total diet, food items should also be taken into account for their potential based on different food components for the DMFT index. Similar to the study conducted by Zaki et al., most of the HEI components and between the DMFT index groups a significant relationship was not found in our study (35). These findings show that in the older childhood period no statistically significant difference related to dental caries or DMFT index and diet quality according to HEI-2015. One of the reasons for this condition might be related to the age group of the study population. There are individuals with mixed dentition in the age range examined in this study. The expressive power of DMFT in the mixed dentition is limited. Besides, $24 \mathrm{~h}$ recall method depended on the declaration and ability to remember all day consumption for parents and their children. The main reason for this situation might be shown as the children participating in the study could not meet the HEl-2015 "adequacy components" following the recommendations on an individual basis or they remained low in the "moderation components" such as added sugar.

There is a dynamic relationship between plaque formation and oral microflora called "The ecological plaque hypothesis". Dental plaque-induced oral diseases such as dental caries are not species specific but are caused by changes in the environment that lead to an ecological shift favouring the growth of dental caries (39). From this point of view lactic acid bacteria can produce acid and survive in an acidic environment, caries formation has been associated with high lactobacillus counts in the oral flora $(40,41)$. In present study, It was observed that children have lactobacilli in their saliva samples had more decayed teeth $(p<0,05)$. This significant difference confirms that in addition to S.mutans, Lactobacillus bacteria also cause caries formation. In parallel with the study performed by Bhayat et al., The DMFT index of children with lactobacilli in saliva samples is higher, but the difference is not statistically significant (41). The presence of caries-causing bacteria depends on oral hygiene practice, snacking habit as well as saliva flow and high bacterial infection gives a sign of poorer oral hygiene status.

The 24-hour recall food intake data gathered from participants confined to only one day and 98 children who applied to Marmara University Faculty of Dentistry, Pedodontics Clinic in a certain time interval were proven to be among the study's primary limitations.

\section{CONCLUSION}

Childhood is one of the most important periods of life for children who becoming individuals. A good quality diet and good oral health are important factors contributing to health and quality of life. Further studies are needed on eating indices, which provide an accurate and reliable measurement of the cariogenicity of the daily diet consumed by individuals. Additionally, oral health education should be integrated into the nutrition education included in the school education of children.

Acknowledgment: This study was supported by Marmara University Research Council (BAPKO, SAG-CYLP-070.317.0090).

\section{REFERENCES}

[1] Petersen PE. The World Oral Health Report 2003: continuous improvement of oral health in the 21st century - the approach of the WHO Global Oral Health Programme. Community Dentistry and Oral Epidemiology 2003;32(1): 3-24.

[2] Kassebaum NJ, Bernabé E, Dahiya M, Bhandari B, Murray CJ, Marcenes W. Global burden of untreated caries: a systematic review and metaregression, J Dent Res 2015;94:650-658.

[3] Manohar N, Hayen A, Fahey P, Arora A. Obesity and dental caries in early childhood: A systematic review and metaanalyses. Obes Rev 2020;21(3): e12960. doi: 10.1111/ obr.12960.

[4] Jackson SL, Vann WF Jr, Kotch JB, Pahel BT, Lee JY. Impact of poor oral health on children's school attendance and performance. Am J Public Health 2011; 101:1900-1906.

[5] Touger-Decker R, Mobley C. Academy of nutrition dietetics: position of the academy of nutrition and dietetics: oral health and nutrition. J Acad Nutr Diet 2013;113(5): 693-701.

[6] Lueangpiansamut J, Chatrchaiwiwatana S, Muktabhant B, Inthalohit W. Relationship between dental caries status, nutritional status, snack foods, and sugar-sweetened beverages consumption among primary schoolchildren grade 4-6 in Nongbua Khamsaen school, Na Klang district, Nongbua Lampoo Province, Thailand. J Med Assoc Thai 2012;95(8): 1090-1097.

[7] Rugg-Gunn AJ, Nunn JH. Nutrition, diet and oral health. Oxford University Press. 1999.

[8] Krebs-Smith SM, Pannucci TE, Subar AF, Kirkpatrick SI, Lerman $\mathrm{JL}$, Tooze JA, et al. Update of the healthy eating index: HEI2015. J Acad Nutr Diet 2018;118(9): 1591-1602.

[9] Guenther PM, Casavale KO, Reedy J, Kirkpatrick SI, Hiza HA, Kuczynski KJ, Krebs-Smith SM. Update of the healthy eating index: HEl-2010. Journal Acad Nutr Diet, 2013;113(4): 569580.

[10] Reedy J, Lerman JL, Krebs-Smith SM, Kirkpatrick SI, Pannucci $\mathrm{TE}$, Wilson MM, et al. Evaluation of the Healthy Eating Index-2015. J Acad Nutr Diet 2018;118(9):1622-1633.

[11] World Health Organisation (2018). Fact Sheet No 394. Available from: https://www.who.int/en/news-room/factsheets/detail/healthy-diet 
[12] Hacettepe Üniversitesi, Sağlık Bilimleri Fakültesi, Beslenme ve Diyetetik Bölümü. Türkiye'ye özgü besin ve beslenme rehberi. 1. Baskı. ISBN 978-975-491-408-5. Ankara 2015.

[13] Meurman JH, Stamatova IV. Probiotics: evidence of oral health implications. Folia Med (Plovdiv). 2018;60(1):21-29.

[14] Hasslöf P, Stecksén-Blicks C. Chapter 10: Probiotic Bacteria and Dental Caries. In The Impact of Nutrition and Diet on Oral Health Karger Publishers 2020;28:99-107.

[15] Ndanu TA, Aryeetey R, Sackeyfio J, Otoo G, Lartey A, Opintan $\mathrm{JA}$, et al. Streptococcus mutans and Lactobacillus species infection in obese and non-obese school children in Accra, Ghana. J Obes Overweig 2015;1(1): 1-5.

[16] World Health Organization. Oral health Surveys: basic methods. World Health Organization. 4th ed. Geneva;1997.

[17] World Health Organization. Oral health surveys: basic methods. World Health Organization. 5 th ed.2013.

[18] World Health Organization AnthroPlus. https://www. who.int/toolkits/growth-reference-data-for5to19years/ applicationtools\#: :text=WHO\%20AnthroPlus\%20is\%20a\%20 software,the\%20three\%20indicators\%20that\%20apply.

[19] Angelopoulos P, Kourlaba G, Kondaki K, Fragiadakis GA, Manios Y. Assessing children's diet quality in Crete based on Healthy Eating Index: the Children Study. Eur J Clin Nutr 2009;63(8): 964-969.

[20] Ravindran S, Chaudhary M, Gawande M. Enumeration of salivary Streptococci and Lactobacilli in children with differing caries experiences in a rural Indian population. Int Sch Res Notices 2013;2013.

[21] Moynihan P, Petersen PE. Diet, nutrition and the prevention of dental diseases. Public health Nutr 2004;7(1a): 201-226.

[22] Holt K, Barzel R. Oral Health and Learning: When Children's Health Suffers, So Does Teir Ability to Learn (3rd ed.). Washington, DC: National Maternal and Child Oral Health Resource Center. 2013.

[23] Paglia L. WHO: healthy diet to prevent chronic diseases and caries. Eur J Paediatr Dent, 2018;19(1): 5-5.

[24] İnan-Eroğlu E, Özşin-Özler C, Erçim RE, Büyüktuncer Z, UzamışTekçiçek M, Güçiz-Doğan B. Is diet quality associated with early childhood caries in preschool children? A descriptive study. Turk J Pediatr 2017;59(5): 537-547.

[25] Sağlık Bakanlığı. Türkiye Beslenme ve Sağlık Araştırması Beslenme Durumu ve Alışkanlıklarının Değerlendirilmesi Sonuç Raporu, 2010;1-636. (Turkish)

[26] Petersen PE, Bourgeois D, Ogawa H, Estupinan-Day S, Ndiaye C. The global burden of oral diseases and risk to oral health. Bulletin of the World Health Organization. 2005;83(9): 661669

[27] Doğan-Güçiz B, Gökalp S. Türkiye'de Diş Çürüğü Durumu ve Tedavi Gereksinimi, 2004. Hacettepe Diş Hekimliği Fakültesi Dergisi. 2008;32(2): 45-57. (Turkish)

[28] Altun C, Güven G, Başak F, Akbulut E. Altı-onbir yaş grubu çocukların ağız-diş sağlığı yönünden değerlendirilmesi. Gülhane Tıp Dergisi. 2005;47: 114-118. (Turkish)
[29] Güler Ç, Eltas A, Güneş D, Görge, VA, Ersöz M. Malatya ilindeki 7-14 yaş arası çocukların ağız-diş sağlığının değerlendirilmesi. İnönü Üniversitesi Sağıık Bilimleri Dergisi 2012;1(2): 19-24. (Turkish)

[30] Namal N, Ertem-Vehid H, Vehid S, Can G, Altı-On İki Yaş Grubu Çocukların Diş Sağlığını Etkileyen Anneye Ait Faktörlerin Araştırılması. Çocuk Dergisi 200);9(3): 123-126. (Turkish)

[31] Köse S, Güven D, Mert E, Eraslan E, Esen S. 12-13 yaş grubu çocuklarda oral hijyen eğitiminin etkinliği. Journal of Anatolia Nursing and Health Sciences 2010;13(4): 44-52. (Turkish)

[32] Zukanovic A, Muratbegovic A, Kobaslija S, Markovic N, Ganibegovic M, Beslagic E. Relationships between socioeconomic backgrounds, caries associated microflora and caries experience in 12-year-olds in Bosnia and Herzegovina in 2004. Eur J Paediatr Dent 2008;9(3): 118-124.

[33] Eğri M, Kayaoğlu A, Önder Y, Çıtıl R. Tokat II Merkezindeki İlköğretim 12 Yaş Öğrencilerde DMFT İndeksi ve iliş̧kili Faktörler. Gaziosmanpaşa Üniversitesi Tıp Fakültesi Dergisi. 2015;7(3): 198-207. (Turkish)

[34] Gökalp S, Güçiz-Doğan B, Tekçiçek M, Berberoğlu A, Ünlüer Ş. Beş, On İki ve On Beş Yaş Çocukların Ağız Diş Sağlığı Profili, Türkiye-2004. Hacettepe Diş Hekimliği Fakültesi Dergisi 2007;31(4):3-10. (Turkish)

[35] Zaki NA, Dowidar KM, Abdelaziz WE. Assessment of the Healthy Eating Index-2005 as a predictor of early childhood caries. Int J Paediatr Dent 2015;25(6), 436-443.

[36] Nunn ME, Braunstein NS, Kaye EK, Dietrich T, Garcia RI. Henshaw MM. Healthy eating index is a predictor of early childhood caries. J Dent Res 2009;88(4), 361-366.

[37] Vundavalli S, Nagarajappa AK, Doppalapudi R, Alhabarti AS, Aleiadah ASA, Alruwili MNH. Association between healthy eating index, body mass index, and early childhood caries in schoolchildren of Sakaka, KSA: A case-control study. J Indian Assoc Public Health Dent 2019;17(4): 306.

[38] Kaye EA, Sohn W, Garcia RI. The Healthy Eating Index and coronal dental caries in US adults: National Health and Nutrition Examination Survey 2011-2014. J Am Dent Assoc 2020;151(2): 78-86.

[39] Marsh PD. Microbial ecology of dental plaque and its significance in health and disease. Adv Dent Res, 1994;8(2): 263-271.

[40] Aas JA, Griffen AL, Dardis SR, Lee AM, Olsen I, Dewhirst FE. Bacteria of dental caries in primary and permanent teeth in children and young adults. J Clin Microbiol 2008;46:14071417.

[41] Bhayat A, Ahmad MS, Bakeer H. Correlating dental caries with oral bacteria and the buffering capacity of saliva in children in Madinah, Saudi Arabia. J Int Soc Prev Community Dent 2013;3(1):38-43. 